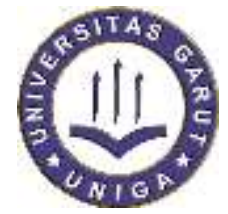

\title{
KEMELIMPAHAN GULMA GULMA PADI SAWAH (Oryza sativa L.) PADA KETINGGIAN DAN SISTEM TANAM YANG BERBEDA
}

\section{Abundance of weeds in rice fields (Oryza sativa L.) at different heights and planting systems}

\author{
Jenal Mutakin ${ }^{1)}$ \\ ${ }^{1)}$ Program Studi Agroteknologi Fakultas Pertanian Universitas Garut \\ Jl. Raya Samarang No.52A, Tarogong Kaler, Kabupaten Garut, Jawa Barat 44151 \\ e-mail : jenalmutakin@uniga.ac.id
}

\begin{abstract}
Abstrak
Penelitian bertujuan untuk mengetahui pengaruh ketinggian tempat dan sistem tanam terhadap kelimpahan gulma padi sawah pergolongan di kabupaten Garut dengan menggunakan metode survai yang dilakukan pada dua ketinggian $(\mathrm{T})$ yaitu $\mathrm{t}_{1}$ dataran rendah dan $\mathrm{t}_{2}$ dataran tinggi pada dua sistem tanam (S) yaitu; $\mathrm{s}_{1}$ sistem tanam Sistem of Rice Intensification (S.R.I) dan $\mathrm{s}_{2}$ sistem tanam konvesional. masing- masing diulang 6 kali. data yang diperoleh kemudian dianalisis dengan mengunakan ANOVA dan jika terjadi pengaruh nyata dilakukan uji lanjut LSD pada taraf 5\%. Hasil penelitian diketahui terjadi interaksi antara ketinggian tempat dan sistem tanam terhadap kelimpahan gulma padi sawah, pada kelimpahan spesies gulma golongan berdaun lebar, spesies gulma golongan berdaun sempit, populasi gulma berdaun sempit. Kombinasi dataran rendah dan sistem tanam konvensional $\left(\mathrm{t}_{1} \mathrm{~s}_{2}\right)$ nenunjukkan rata-rata spesies gulma tertingi, kombinasi dataran tinggi dan sistem tanam konvensional $\left(\mathrm{t}_{2} \mathrm{~S}_{2}\right)$ menunjukkan rata-rata golongan gulma berdaun sempit tertinggi dan kombinasi dataran rendah dan sistem tanam S.R.I $\left(\mathrm{t}_{1} \mathrm{~s}_{1}\right)$ menunjukkan rata-rata populasi golongan gulma berdaun sempit tertinggi.
\end{abstract}

Kata Kunci : gulma, kelimpahan, ketinggian, padi sawah, sistem tanam,

\section{ABSTRACT}

This study aims to determine the effect of altitude and planting system on the abundance of paddy rice weeds in Garut district by using a survey method carried out at two altitudes $(T)$, namely $t 1$ lowland and $t 2$ highland in two cropping systems $(S)$, namely; $\mathrm{s}_{1}$ cropping System of Rice Intensification (S.R.I) and $\mathrm{s}_{2}$ conventional cropping system. each repeated 6 times. The data obtained were then analyzed using ANOVA and if there was a significant effect, the LSD continued test was carried out at the 5\% level. The results showed that there was an interaction between altitude and planting system on the abundance of lowland rice weeds, the abundance of broadleaf weed species, narrow leaf weed species, and narrow leaf weed populations. The combination of lowland and conventional cropping systems (t1s2) shows the highest average weed species, the combination of upland and conventional cropping systems ( $t 2 s 2)$ shows the average of the highest narrow-leaf weeds and the combination of lowland and SRI cropping systems (t1s1) shows average -the highest average population of narrow-leaved weed 
Keywords: weeds, abundance, altitude, lowland rice, cropping system,

\section{Pendahuluan}

Agroekologi di Indonesia sangat beragam, hal ini diantaranya dipengaruhi oleh perbedaan ketinggian tempat. Ketinggian tempat mempengaruhi iklim suatu daerah. Setiap pertambahan ketinggian $100 \mathrm{~m}$ dpl. terjadi penurunan suhu $1{ }^{0} \mathrm{C}$, sehingga pada ketinggian yang berbeda iklimnya akan berbeda pula. Ketinggian tempat merupakan salahsatu komponen agroekologi yang dapat mempengaruhi terhadap produktifitas suatu tanaman. Hal ini disebabkan tumbuhan memiliki daya adaptasi yang dibatasi di antaranya oleh iklim, ketinggian tempat, kesuburan tanah dan jenis tanah. Varietas padi yang unggul untuk suatu daerah belum tentu menunnjukkan keunggulan yang sama di daerah lain, karena di Indonesia sangat beragam agroekologinya, termasuk dataran tinggi.

Budidaya padi di Indonesia dilakukan secara turun temurun, tradisi ini terus mengalami perbaikan sejalan dengan perkembangan teknologi budidaya. Budidaya padi sawah secara konvensional terus berkembang seiring dengan meningkatnya penggunaan input bahan kimia baik pupuk maupun pestisida dan terus menurunnya pemberian bahan organik, sampai tidak sama sekali. Hal ini berdampak kepada rusaknya kondisi lahan dan lingkungan, tanah menjadi miskin bahan organik dan sangat bergantung kepada pasokan bahan kimia. Tanah dengan kandungan bahan organik rendah dapat menyebabkan rusaknya sifat fisik dan biologi tanah (Helmi, 2003)

Sejalan dengan upaya perbaikan produktivitas lahan, telah dikembangkan konsep system tanam padi berkelanjutan yang memperhatikan kondisi lingkungan. System ini disebut System of Rice Intensification (S.R.I.) Dalam upaya meningkatkan ketersediaan unsur hara dan kesehatan tanah yang semakin menurun, pada system S.R.I., pemupukan hanya dilakukan dengan bahan organik (Kuswara dan Sutaryat 2003). Pemberian input bahan organik pada tanaman selain menambah kesuburan tanah, meningkatkan kehidupan organisme tanah seperti cacing tanah, juga dapat menimbulkan gulma tumbuh subur dan lebih beragam, hal ini disebabkan bahan organik yang berasal dari tumbuhan dan membawa biji-biji gulma, apalagi bahan organik yang masih mentah.

Gulma sama halnya dengan tumbuhan lain memerlukan lingkungan yang sesuai untuk pertumbuhannya. Gulma maupun tanaman mempunyai keperluan dasar yang sama untuk pertumbuhan dan perkembangan yang normal yaitu unsur hara, air, cahaya, ruang tumbuh dan $\mathrm{CO} 2$. Persaingan terjadi bila unsur- unsur penunjang pertumbuhan tersebut tidak tersedia dalam jumlah yang cukup bagi keduanya (Rahayu, 2002)

Gulma yang tumbuh di pertanaman padi meliputi gulma berdaun lebar, gulma berdaun sempit dan teki-tekian. Kehilangan hasil padi akibat gulma berkisar antara 6-87 \%. Data yang lebih rinci penurunan hasil padi secara nasional akibat gangguan gulma 15-42 \% untuk padi sawah dan padi gogo 47-87 \% (Pitoyo, 2006 dalam Kastanja, 2011). Menurut Booth (2003), gulma mempunyai sifat sangat kompetitif karena mempunyai mekanisme perkembangbiakan yang efisien yaitu mampu berkembangbiak secara generatif dengan menghasilkan banyak biji dan secara vegetatif, sehingga sangat menurunkan hasil tanaman budidaya, Karena itu pertumbuhan gulma perlu 
dikendalikan. Penelitian ini bertujuan untuk mengetahui pengaruh ketinggian dan sistem terhadap kemelimpahan gulma pergolongan pada padi sawah (Oryza sativa L.)

\section{Metodologi}

Penelitian dilaksanakan pada lahan sawah milik petani yang menggunakan sistem tanam S.R.I dan konvensional pada dataran rendah maupun dataran tinggi ketinggian 400 meter dpl, sampai 800 dpl di Kabupaten Garut. Bahan yang digunakan adalah tanaman padi kultivar Sarinah yang ditanam pada ketinggian yang berbeda. Alat yang digunakan adalah prim ukuran $50 \mathrm{~cm}$ x50 cm , kantong plastik, kertas label.

Metode yang digunakan adalah kualitatif (weeds survai) dan kuantitatif (identifikasi). Yang dilakukan pada dua ketinggian $(\mathrm{T})$ yaitu $\mathrm{t}_{1}$ dataran rendah dan $\mathrm{t}_{2}$ dataran tinggi. dan dua sistem tanam (S) yaitu; $\mathrm{s}_{1}$ sistem tanam S.R.I dan $\mathrm{s}_{2}$ sistem tanam konvesional masing- masing diulang 6 kali. Data yang diperoleh kemudian dianalaisis dengan mengunakan ANOVA dan jika terjadi pengaruh nyata baik interaksi, maupun mandiri dilakukan uji lanjut LSD pada taraf 5\%. Pengambilan sampel pada setiap plot dilakukan dengan menggunakan prim ukuran $50 \mathrm{~cm}$ x $50 \mathrm{~cm}$. sampel gulma yang diperoleh dari setiap plot kemudian dipisahkan per kelompok dan dihitung berdasarkan jenis dan individunya.

\section{Hasil dan Pembahasan}

Hasil survai terhadap keragaman gulma di daratan tinggi dan dataran rendah pada sistem tanam organik dan konvensional ditemukan 19 spesies gulma yang meliputi gulma golongan berdaun lebar, gulma berdaun sempit dan gulma golongan teki. Berdasarkan hasil identifikasi diketahui; 1) gulma golongan berdaun lebar terdapat 11 jenis yaitu; Azolla pinnata, Pistia stratiodes, Salvinia molesta, Monochoria vaginalis, Limonocharis flave, Oxalis corniculata L., Marsilea clover, Plantago major, Ludwigia octovalvis, Ludwigia adscendens, dan Polygonum hydropiper L.,2) gulma golongan berdaun sempit terdapat 6 jenis yaitu; Echinocloa crus-galli, Bolboschoenus maritimus, Dactylotenum aegyptium, Paspalum dictichum L., Cynodon dactylon, Rottboellia cochinchinensis, dan 3) gulma golongan teki 2 Jenis yaitu Fimbristylis miliaceae, Cyperus difformin L,. Keadaan ini sesuai dengan yang kemukakan Mercado (1979) dalam Lamid (2011), bahwa populasi gulma padi sawah dapat digolongkan menjadi tiga golongan, yaitu gulma gulma berdaun lebar, berdaun sempit, dan teki. Ketiga golongan gulma tersebut ditemukan pada masing-masing perlakuan yang menjadi objek pengambilan sampel.

Keberadan spesies dan populasi gulma pada pertanaman padi nyata dipengaruhi oleh faktor perlakuan ketinggian tempat dan sistem tanam. Kelimpahan spesies gulma berdaun lebar lebih banyak ditemukan di pertanaman padi dibandingkan dengan jenis gulma berdaun sempit dan teki. Berdasarkan hasil penelitian diketahui spesies gulma golongan berdaun lebar ditemukan banyak tumbuh di dataran rendah pada sistem tanam konvesional, gulma berdaun sempit banyak ditemukan tumbuh di dataran tinggi pada sistem konvensimnal dan populasi gulma golongan berdaun sempit banyak ditemukan tumbuh pada dataran rendah pada sistem S.R.I, sedangkan pengaruh mandiri ketinggian 
tempat dan sistem tanam menunjukkan pengaruh nyata terhadap gulma golongan teki. Pada ketinggian tempat populasi gulma tertinggi ditemukan banyak tumbuh pada dataran tinggi dan pada sistem tanam tanam golongan teki banyak ditemukan tumbuh pada sistem S.R.I

Siti Rosmanah dan Alfayanti (2016) mengemukakan bahwa berbagai faktor dapat menjadi penyebab adanya perbedaan populasi gulma pada berbagai tempat. sejarah penggunaan lahan mempengaruhi proses perubahan dan perkembangan tumbuhan atau yang lebih dikenal dengan istilah suksesi (Mardiyanti et al 2013),. Hal ini sesuia dengan pernyataan Whitten (1996) dalam Wicaksono (2006), yang menyatakan bahwa pada proses suksesi, komposisi tumbuhan dan hewan yang hidup dan menghuni daerah tersebut juga akan berubah.

\section{KELIMPAHAN SPESIES GULMA GOLONGAN BERDAUN LEBAR}

Berdasarkan analisis data terhadap jenis gulma berdaun lebar diketahui bahwa ketinggian tempat berinteraksi dengan sistem taman (Tabel 1)

Tabel 1. Pengaruh Ketinggian Tempat dan Sistem Tanam terhadap Kemelimpahan Spesies Gulma Berdaun Lebar (spesies)

\begin{tabular}{lcc}
\hline & \multicolumn{2}{c}{ Rata-rata spesies gulma (spesies) } \\
\cline { 2 - 3 } Perlakuan T/S & $\mathrm{s}_{1}$ & $\mathrm{~s}_{2}$ \\
\hline $\mathrm{t}_{1}$ & $3.20 \mathrm{a}$ & $3.46 \mathrm{~b}$ \\
& $\mathrm{~A}$ & $\mathrm{~A}$ \\
$\mathrm{t}_{2}$ & $3.07 \mathrm{a}$ & $1.67 \mathrm{a}$ \\
& $\mathrm{B}$ & $\mathrm{A}$ \\
\hline
\end{tabular}

Keterangan: Nilai rata-rata yang ditandai huruf kecil (vertical) yang berbeda pada satu kolom dan nilai rata-rata yang ditandai huruf besar (horizontal ) yang berbeda pada satu baris menunnjukkan berbeda nyata menurut uji LSD pada taraf $5 \%$

Dari Tabel 1. Diketahui bahwa jenis gulma berdaun lebar di dataran rendah dan dataran tinggi tidak berbeda nyata pada sistem tanam S.R.I., sedangkan pada sistem konvensional jenis gulma berdaun lebar di dataran rendah menunjukkan rata-rata tertinggi yang berbeda nyata dengan jenis gulma daun lebar di dataran tinggi. Pada sistem S.R.I. dan konvensional di dataran rendah rata-rata jenis gulma menunjukkan tidak berbeda nyata, tetapi di dataran tinggi jenis gulma berdaun lebar pada sistem S.R.I. menunjukkan rata-rata jenis gulma bedaun lebar tertinggi yang berbeda nyata dengan sistem konvensional.

\section{KELIMPAHAN POPULASI GULMA GOLONGAN BERDAUN LEBAR}

Hasil analisis rata-rata populasi gulma golongan berdaun lebar pada ketinggian tempat dan sistem tanam menunjukkan tidak berinteraksi, namun secara mandiri menunjukkan pengaruh nyata (Tabel 2). Dari tabel 2 diketahui bahwa populasi gulma berdaun lebar di dataran rendah lebih banyak dan berbeda nyata, jika dibandingkan dengan gulma di dataran tinggi, sedangkan pada sistem tanam populasi gulma terbanyak berada pada sistem S.R.I. yang berbeda nyata dengan sistem konvensional. Keadaan ini membuktukan bahwa perbedaan tempat dapat mempengaruhi populasi gulma. 
Tabel 2. Pengaruh Ketinggian Tempat dan Sistem Tanam terhadap Kelimpahan Populasi gulma Golongan Berdaun Lebar

\begin{tabular}{cc}
\hline Perlakuan & rata rata populasi gulma (individu) \\
\hline Ketinggian Tempat $(\mathrm{T})$ & \\
$\mathrm{t}_{1}$ & $19.64 \mathrm{a}$ \\
$\mathrm{t}_{2}$ & $8.10 \mathrm{~b}$ \\
\hline
\end{tabular}

Sistem Tanam (S)

$\mathrm{s}_{1} \quad 16.70 \mathrm{a}$

$\mathrm{S}_{2} \quad 11.07 \mathrm{~b}$

keterangan :Angka rata-rata yang diikuti huruf yang sama tidak berbeda nyata menurut uji LSD dalam taraf nyata 5\%

\section{KELIMPAHAN JENIS GULMA GOLONGAN BERDAUN SEMPIT}

Berdasarkan analisis data terhadap jenis gulma berdaun sempit diketahui bahwa ketinggian tempat berinteraksi dengan sistem taman.

Tabel 3. Pengaruh Ketinggian Tempat dan Sistem Tanam terhadap Kelimpahan Jenis Gulma Golongan Berdaun Sempit

\begin{tabular}{lcc}
\hline Perlakuan T/S & rata-rata Jenis Gulma (spesies) \\
\cline { 2 - 3 } & $\mathrm{s}_{1}$ & $\mathrm{~s}_{2}$ \\
\hline $\mathrm{t}_{1}$ & $0.73 \mathrm{a}$ & $0.20 \mathrm{a}$ \\
& $\mathrm{B}$ & $\mathrm{A}$ \\
$\mathrm{t}_{2}$ & $0.93 \mathrm{a}$ & $2.27 \mathrm{~b}$ \\
& $\mathrm{~A}$ & $\mathrm{~B}$ \\
\hline
\end{tabular}

Keterangan: Nilai rata-rata yang ditandai huruf kecil (vertical) yang berbeda pada satu kolom dan nilai rata-rata yang ditandai huruf besar (horizontal ) yang berbeda pada satu baris menunnjukkan berbeda nyata menurut uji LSD pada taraf $5 \%$

Dari Tabel 3. Diketahui bahwa jenis gulma berdaun sempit di dataran rendah dan dataran tinggi tidak berbeda nyata pada sistem tanam S.R.I., sedangkan pada sistem konvensional jenis gulma berdaun sempit di dataran tinggi menunjukkan rata-rata tertinggi yang berbeda nyata dengan jenis gulma daun sempit di dataran rendah. Pada sistem S.R.I. dan konvensional rata-rata jenis gulma berdaun sempit menunjukkan berbeda nyata. Jenis gulma berdaun sempit pada sistem organik di dataran rendah menunjukkan rata -rata tertinggi yang berbeda nyata dengan sistem konvensional sedangkan di dataran tinggi sistem konvensional menunjukkan rata-rata terninggi yang berbeda nyata dengan sistem S.R.I.

Ketinggian tempat dan sistem tanam saling mempengaruhi terhadap keragaman jenis dan populasi gulma berdaun sempit. Di dataran tinggi kelimpahan jenis gulma daun sempit tertinggi ditemukan pada sistem konvensional, sedangkan pada sistem S.R.I., antara dataran tinggi dan dataran rendah tidak berpengaruh nyata. Sistem tanam pada dataran rendah, sistem S.R.I. menunjukkan kelimpahan spesies gulma daun sempit tertinggi, sedangkan pada dataran tinggi sistem konvensional menunjukkan rata-rata kelimpahan jenis gulma tertinggi.

\section{KELIMPAHAN POPULASI GULMA GOLONGAN BERDAUN SEMPIT}


Berdasarkan analisis data terhadap kelimpahan populasi gulma golongan berdaun sempit diketahui bahwa ketinggian tempat berinteraksi dengan sistem taman. Dari Table 4. diketahui bahwa kelimpahan populasi gulma golongan berdaun sempit di dataran rendah pada sistem S.R.I. menunjukkan rata-rata tertinggi yang berbeda nyata dengan populasi gulma di dataran tinggi, sedangkan pada sistem konvensional ketinggian tempat terhadap kelimpahan populasi gulma golongan berdaun sempit tidak menunjukkan perbedaan yang nyata (Tabel 4).

Tabel 4. Pengaruh Ketinggian Tempat dan Sistem Tanam terhadap dan Kelimpahan Populasi Gulma Golongan Berdaun Sempit

\begin{tabular}{lcc}
\hline & \multicolumn{2}{c}{ Rata-rata popusi gulma (individu) } \\
\cline { 2 - 3 } Perlakuan T/S & $\mathrm{s}_{1}$ & $\mathrm{~s}_{2}$ \\
\hline $\mathrm{t}_{1}$ & $13.80 \mathrm{~b}$ & $1.53 \mathrm{a}$ \\
& $\mathrm{B}$ & $\mathrm{A}$ \\
$\mathrm{t}_{2}$ & $4.40 \mathrm{a}$ & $7.73 \mathrm{a}$ \\
& $\mathrm{A}$ & $\mathrm{A}$ \\
\hline
\end{tabular}

Keterangan: Nilai rata-rata yang ditandai huruf kecil (vertical) yang berbeda pada satu kolom dan nilai rata-rata yang ditandai huruf besar (horizontal ) yang berbeda pada satu baris menunnjukkan berbeda nyata menurut uji LSD pada taraf $5 \%$

Pada sistem S.R.I. dan konvensional rata-rata populasi gulma berdaun sempit menunjukkan berbeda nyata. Populasi gulma golongan berdaun sempit pada sistem S.R.I. di dataran rendah menunjukkan rata -rata tertinggi yang berbeda nyata dengan sistem konvensional, sedangkan di dataran tinggi sistem tanam tidak menunjukkan pengaruh nyata terhadap populasi gulma berdaun sempit populasi gulma berdaun sempit di dataran rendah lebih banyak pada sistem S.R.I.

\section{KELIMPAHAN JENIS GULMA GOLONGAN TEKI}

Hasil analisis rata-rata populasi gulma golongan teki pada ketinggian tempat dan sistem tanam tidak berinteraksi, namun secara mandiri menunjukkan pengaruh nyata (Tabel 5).

Tabel 5. Pengaruh Ketinggian Tempat dan Sistem Tanam terhadap Kelimpahan Jenis gulma Golongan Teki

\begin{tabular}{lcc}
\hline & \multicolumn{2}{c}{ rata-rata } \\
\cline { 2 - 3 } Perlakuan & jenis gulma (spesies) populasi gulma (individu) \\
\hline Ketinggian Tempat (T) & $0.50 \mathrm{a}$ & $4.80 \mathrm{a}$ \\
$\mathrm{t}_{1}$ & $0.63 \mathrm{a}$ & $8.37 \mathrm{a}$ \\
$\mathrm{t}_{2}$ & & \\
\hline Sistem Tanam (S) & $0.86 \mathrm{~b}$ & $12.10 \mathrm{~b}$ \\
$\mathrm{~s}_{1}$ & $0.27 \mathrm{a}$ & $1.10 \mathrm{a}$ \\
$\mathrm{s}_{2}$ &
\end{tabular}

keterangan : Angka rata-rata yang diikuti huruf yang sama tidak berbeda nyata menurut uji LSD dalam taraf nyata $5 \%$

Dari tabel 5 diketahui bahwa ketinggian tempat tidak berpengaruh nyata terhadap spesies gulma golongan teki, namun pada populasi gulma menunjukkan pengaruh yang 
nyata. Pada perlakuan ketinggian tempat rata-rata populasi golongan gulma teki tertinggi ditemukan pada dataran tinggi dan berbeda nyata jika dibandingka dengan di dataran rendah. Sedangkan pada sistem tanam golongan gulma tertinggi terdapat pada sistem S.R.I yang berbeda nyata dengan sistem konvensional.

\section{Kesimpulan}

Berdasarkan hasil penelitian mengenai pengaruh sistem tanam pada ketinggan tempat yang brbeda dapat disimpulkan sebagai berikut

1. Terjadi intekasi antara ketinggian tempat dan sistem tanam terhadap kelimpahan gulma padi sawah, pada kelimpahan spesies gulma golongan berdaun lebar, spesies gulma golongan berdaun sempit, populasi gulma berdaun sempit.

2. Kombinasi dataran rendah dan sistem tanam konvensional $\left(\mathrm{t}_{1} \mathrm{~s}_{2}\right)$ nenunjukkan rata-rata spesies gulma tertingi, kombinasi dataran tinggi dan sistem tanam konvensional $\left(\mathrm{t}_{2} \mathrm{~S}_{2}\right)$ menunnjukkan rata-rata golongan gulma daun sempit tertinggi dan kombinasi daratan rendah dan sistem tanam S.R.I menunjukkan rata-rata populasi golongan gulma berdaun sempit tertinggi.

\section{Daftar Pustaka}

Booth, B.D., S.D. Murphy and C.J. Swanton. 2003. Weed Ecology in Natural Agricultural System. GABI Publishing Cambrige USA.

Helmi, 2003. Pemberian Kompos Jerami dan Pupuk Kandang pada Padi sawah. Kebijakan Perberasan dan Inovasi Teknologi Padi Hal. 25

Kastanja, A.Y. 2011. Identifikasi Jenis dan Dominansi Gulma Pada Pertanian Padi Gogo (Studi Kasus di Kecamatan Tobelo Barat, Kabupaten Halmahera Utara). Jurnal Agroforestry, Vol. VI No.1 Maret 2011

Kuswara dan A. Sutaryat, 2003. Dasar Gagasan dan Praktek Tanam Padi Metode S.R.I. Kelompok Studi Petani (KSP) Ciamis.

Lamid, Z. 2011. Integrasi pengendalian gulma dan teknologi tanpa olah tanah pada usaha tani padi sawah menghadapi perubahan iklim. Jurnal Pengembangan Inovasi Pertanian 4 (1) : 14-28.

Mardiyanti, D. E., K. P. Wicaksono dan M. Baskara. 2013. Dinamika keanekaragaman spesies tumbuhan pasca pertanaman padi. Jurnal Produksi Tanaman 1 (1) : 2435.

Rahayu, N., 2002. Penentuan Periode Kritis Tanaman Terhadap Kompetisi dengan Gulma. Agrivet Vol.6 No.2 Hal. 138-146

Rosmanah, S. dan Alfayanti 2017. Identifikasi Gulma Pada Dua Agroekosistem yang Berbeda di Kabupaten Seluma Provinsi Bengkulu. Balai Pengkajian Teknologi Pertanian (BPTP) Bengkulu. Prosiding_1_2017/29 
Vol. 5; No. 1 Desember 2020

Halaman 323-330

Wicaksono, K. P. 2006. Analisis rona agroeosistem pengembangan daerah irigasi Mbay Kabupaten Bajwa, Flores, Nusa Tenggara Timur. Jurnal Habitat 17 (1) : 6 